\title{
Social Evolution
}

\section{Liberdade}

Poesia intitulada "Liberdade", escrita em 01 de julho de 2019, às 07:17 AM.

Palavras-chave: Poesia; Liberdade.

\section{Freedom}

Poetrything "Freedom", written July 1, 2019, at 07:17 AM.

Keywords: Poetry; Freedom.

Topic: Registro de Obras Artísticas

Reviewed anonymously in the process of blind peer.

Cláudia Catarina de Oliveira Andrade Brito

Universidade Tiradentes, Brasil

http://lattes.cnpq.br/6228202479459747

catarinaandrade.se@gmail.com
Received: 15/08/2019

Approved: 15/08/2019
Referencing this:

BRITO, C. C. O. A.. Liberdade. Social Evolution, v.3, n.1, p.1-2, 2019 DOI: http://doi.org/10.6008/CBPC2595-430X.2019.001.0001

DOI: 10.6008/CBPC2595-430X.2019.001.0001 


\section{OBRA}

Na pá, o pó

Na corda, o nó

Varrida da dor

Atada de amor

Esse amor plural

Que me faz ser universo

Dentro de minha singularidade

Com asas abertas

Sem voos de despedida

Assento ideias agudas

E desfilo leve pelas ruas

Em mim

Nem camisa, nem força

Tiro a roupa da resistência

E sinto-me nua

Visto apenas o tempo

Que divaga em minhas teias

Pelas tramas da vida

Fluindo todas as coisas

A CBPC - Companhia Brasileira de Produção Científica (CNPJ: 11.221.422/0001-03) detém os direitos materiais desta publicação. Os direitos referem-se à publicação do trabalho em qualquer parte do mundo, incluindo os direitos às renovações, expansões e disseminações da contribuição, bem como outros direitos subsidiários. Todos os trabalhos publicados eletronicamente poderão posteriormente ser publicados em coletâneas impressas sob coordenação da Sustenere Publishing, da Companhia Brasileira de Produção Científica e seus parceiros autorizados. Os (as) autores (as) preservam os direitos autorais, mas não têm permissão para a publicação da contribuição em outro meio, impresso ou digital, em português ou em tradução. Em exceção, os autores da seção especial "Registro de Obras Artísticas (fotografias, músicas, poesias, poemas, sonetos etc.)", existente em periódicos da área "Artes/Música", preservam os direitos autorais e materiais. 